\title{
Seasonal Trend Indicators and Return Periods of Meteorological Drought in the Northern States of Mexico
}

\author{
Omar Llanes Cárdenas ${ }^{1}$, Héctor J. Peinado Guevara ${ }^{2 *}$, Jorge Montiel Montoya ${ }^{1}$, \\ Mariano Norzagaray Campos ${ }^{1}$, Héctor A. González Ocampo ${ }^{1}$, \\ Samuel Campista León ${ }^{3}$ \\ ${ }^{1}$ Instituto Politécnico Nacional, Centro Interdisciplinario de Investigación para el Desarrollo Integral Regional, \\ Unidad Sinaloa (CIIDIR-IPN-Sinaloa); Boulevard Juan de Diós Bátiz Paredes 250, \\ Guasave, Sinaloa, Mexico C.P. 81101 \\ ${ }^{2}$ Universidad Autónoma de Sinaloa, Escuela de Ciencias Económicas Administrativas (UAS-ECEA); \\ Blvd. Juan de Dios Bátiz s/n, Col. San Joachín, Guasave, Sinaloa, México C.P. 81101 \\ ${ }^{3}$ Universidad Autónoma de Sinaloa, Escuela de Biología; Av. Universitarios S/N. Col. Universitarios, \\ Culiacán Rosales, Sinaloa, México C.P. 80013
}

Received: 9 December 2016

Accepted: 12 January 2017

\begin{abstract}
Meteorological drought is an atmospheric condition characterized by a deficiency in the amount of precipitation and increased evapotranspiration. We calculated the magnitudes of average annual seasonal trends (June to September) of the following drought indicators for 1970-2011: average temperature $\left(T_{\text {avg }}\right)$, precipitation (Prec), potential evapotranspiration (PET), standardized precipitation evapotranspiration index (SPEI) on a 24-month scale (SPEI-24), and return periods $(R P)$ of drought (SPEI-24). The indicators were calculated from records of daily $T_{\text {avg }}$ and Prec obtained from 38 CONAGUA (National Water Commission) weather stations located in the northern states of Sinaloa, Baja California Sur, Durango, Chihuahua, and Sonora. PET was calculated by the method of Thornthwaite; drought was calculated by the expression for SPEI-24 based on the calculation of deciles 1, 2, 3, 7, 8, and 9 of Prec; and the RP of SPEI-24 were calculated using the probability distribution function of Gumbel on time scales from 2 to 500 years. The nonparametric Mann-Kendall test was applied. The magnitude of change in the trends was estimated by Sen's method for slopes. SPEI-24 showed positive and negative trends (-0.066 to 0.082). The results have predicted that there will be severe droughts in 2021 and 2036 in the states of Baja California Sur and Sinaloa.
\end{abstract}

Keywords: SPEI-24, precipitation deciles, return periods

*e-mail: hpeinado75@hotmail.com 


\section{Introduction}

Climate change will lead to changes in regimes on cumulative annual average seasonal precipitation (Prec) and evapotranspiration [1], as well as increases in the intensity and number of hurricanes and droughts [2]. [2] collected more than 150 definitions of drought, categorizing them into four main groups: hydrological drought, agricultural drought, socioeconomic drought, and meteorological drought. Meteorological drought is an atmospheric condition characterized by a deficiency in the amount of Prec and an increase in evapotranspiration.
It is normally defined over a region but can manifest as changes in the environment at the local level, causing considerable economic and environmental losses, particularly in regions where most economic activities such as agriculture and aquaculture, among others, are scheduled according to the season [3-9]. Significant trends $(S T)$ in seasonal annual average air temperature $\left(T_{\text {avg }}\right)$ and $P r e c$ can cause $S T$ in the seasonal annual average potential evapotranspiration (PET), and therefore also in the drought of a region $[7,8,10]$. There are various indices that can reliably be used to calculate the meteorological drought of a region. The average annual standardized precipitation

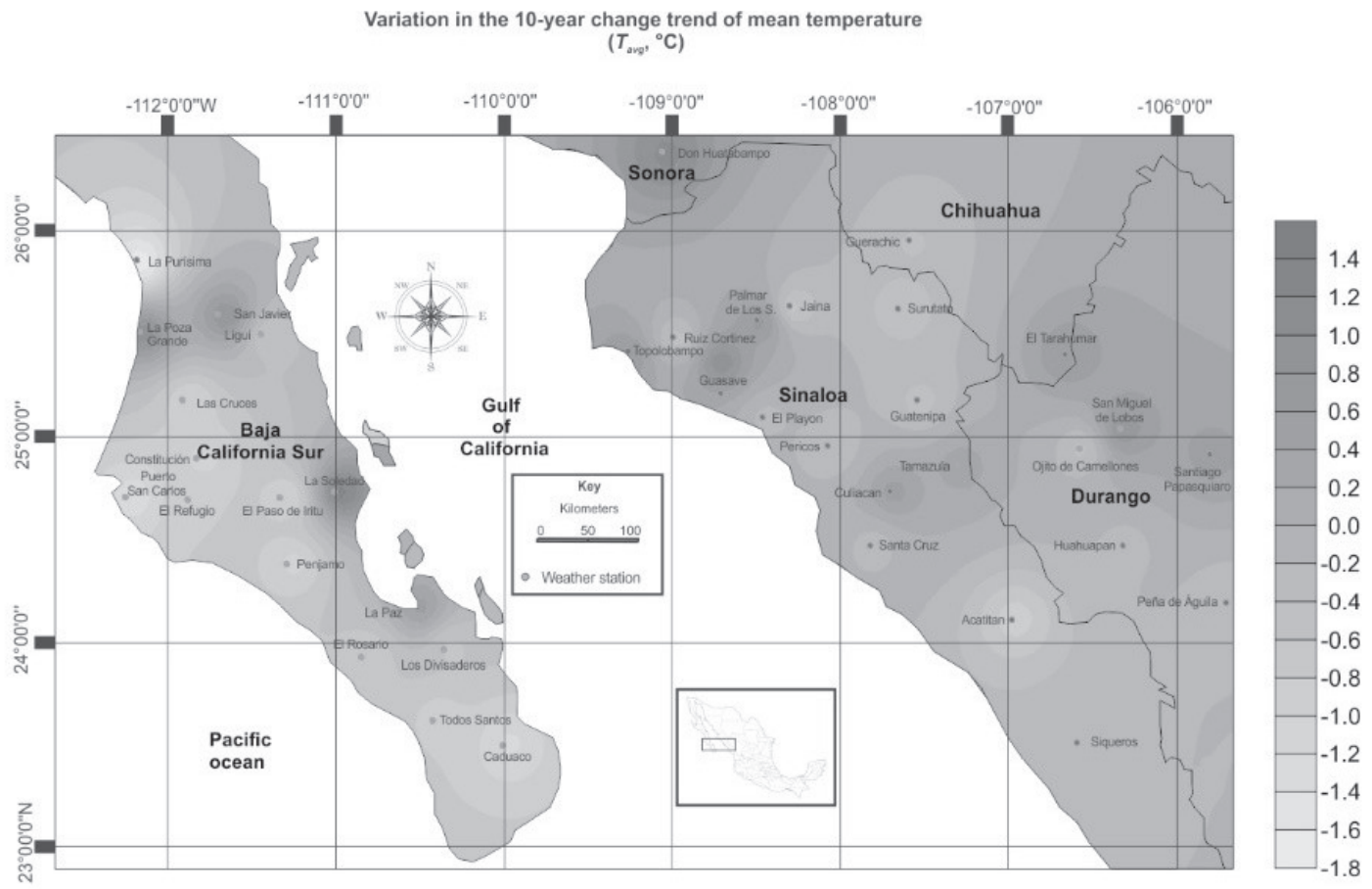

Variations in the 10 -years change trend of mean temperature by weather station (Tavg, ${ }^{\circ} \mathrm{C}$ )
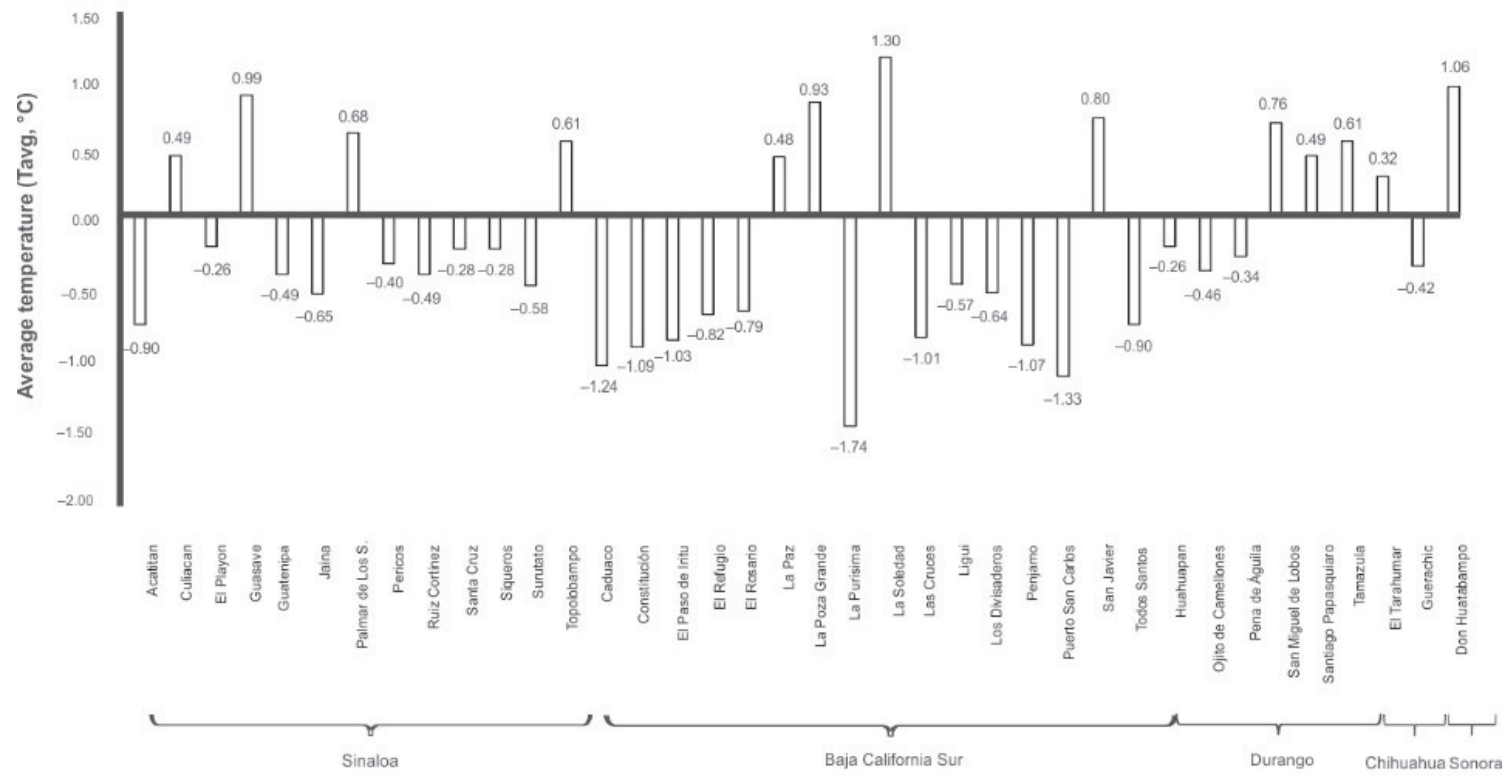

Weather stations

Fig. 1. Magnitude of change trends in $T_{\text {avg }}$ in states in northern Mexico $\left({ }^{\circ} \mathrm{C}\right.$ decade $\left.{ }^{-1}\right)$. 
evapotranspiration index (SPEI) is the only methodology that jointly takes these two indicators (temperature and precipitation) into account [7-9]. [11] found that for greater fidelity, it is advisable to estimate drought on a 24-month scale, mainly because this has been shown to be a suitable timescale to capture low-frequency variability. Drought events that have occurred in regions with arid and semiarid climates, such as West Africa [12], northeastern Brazil [13], and North America [10] have caused the greatest natural disasters associated with these events, including frosts, increased arid areas, decreased soil organic matter, and decreased crop yields, among others, leading to hunger, poverty, and unemployment [14]. The occurrence of these events has been reported by the agricultural industry of northern Mexico in the states of Sinaloa (SIN), Baja California Sur (BCS), Durango (DGO), Chihuahua (CHIH), and Sonora (SON) [15-16]. In northern Mexico, seasonal summer rains (June to September) account for about $60 \%$ of the cumulative annual average Prec $\left(P_{\alpha}\right)$, and the highest temperatures in the year usually fall in summer. [1] has estimated projections for the year 2100 , in which $T_{\text {avg }}$ could reach values above $2^{\circ} \mathrm{C}$.

To accurately analyze $T_{a v g}$, an $S T$ can be divided into positive trends $(P T)$ and negative trends $(N T)$; where a $P T$ indicates an increase in $T_{a v g}$ and an $N T$ indicates a decrease [17-18]. For example, a $P T$ of $T_{\text {avg }}$ indicates warming of a region and an $N T$ indicates cooling. In northern Mexico, despite the existence of climate models on global and regional scales, which can be an important resource for decision makers taking action to counter the effects of climate change, this information is unrepresentative and therefore unsuitable for timely decision making [18]. Because of the lack of regional data on this important issue, the present study was designed to calculate seasonal estimates (June to September) of the magnitude of average annual trends of the following drought indicators: $T_{\text {avg }}$, Prec, PET, SPEI-24, and return periods $(R P)$ of drought (SPEI-24). To do so, $T_{\text {avg }}$ and Prec were calculated using daily data from 38 CONAGUA weather stations from the period 1970-2011. These stations were located in the states of SIN, BCS, DGO, CHIH, and SON. For each station, the SPEI-24 index and the annual averages of $P E T$ were calculated using the methods of [7] and [19]. To identify $S T$ at a confidence level of $95 \%(\alpha=0.05)$ and to generate hypotheses regarding the threats associated with climate change on production systems of the states in the study, the nonparametric Mann-Kendall test was applied to each variable [20]. The magnitude of changes in each variable was calculated using Sen's slope estimator [21]. Representative spatial maps of the variation of the seasonal trend of each variable were constructed using the inverse distance weighting (IDW) interpolation method. According to [22], drought is categorized based on knowledge of deciles $1,2,3,7,8$, and 9 (percentiles $10,20,30,70,80$, and 90 ) of the daily precipitation and variation of SPEI-24 at each weather station. RP of SPEI-24 were calculated for the study states in northern Mexico on time scales of 2, 5, 10, 25, 50, 100, 200, and 500 years according to the Gumbel probability function distribution [23] and the drought classification scale. It was considered important to measure drought in these states because of their economic role in Mexico.

The Guasave Valley in SIN is the most important agricultural region of Mexico, commonly called the "agricultural heart of Mexico." Protecting this valley is vital to ensuring the food sovereignty of the country $[24,25]$. SIN and BCS are distinguished worldwide for their many tourist destinations, including Mazatlán, La Paz, Cabo San Lucas, and San José del Cabo, among others [26], which are sources of foreign exchange and employment. BCS and SIN, because of their climate and environmental richness, are the first and second states respectively with the most Ramsar wetlands in Mexico. DGO contains 12 wetlands of national importance. In the other states in the study, the weather stations have higher elevations $(E)$, which means that there are different thermal floors, and multiple agricultural, forestry, and drought problems. CHIH was selected due to its forest wealth, and the high risk of occurrence of drought. SON was selected because of its species richness of flora and fauna, and its agricultural importance in Mexico [27]. Given the issues raised, the goal of this work was to calculate the summer seasonal trend (June-September) and the RP of SPEI-24 for $2,5,10,25,50,100,100,200$, and 500 years in states in northern Mexico.

\section{Material and Methods}

\section{Study Area and Data Series}

$T_{a v g}$ and Prec were calculated using daily summer data (June-September) collected from 38 CONAGUA(National Water Commission) weather stations in the study states for the period 1970-2011. Most of the time series had continuity issues such as missing data or outliers, so the data were visually inspected, comparing the values from each station with the values from neighboring stations $(\leq 25 \mathrm{~km})$. The reason for the particular time period and

Table 1 Categorization of seasonal drought according to SPEI-24 and deciles 1, 2, 3, 7, 8 and 9 of Prec.

\begin{tabular}{|c|c|c|}
\hline Category & SPEI-24 & Decile \\
\hline $\begin{array}{c}\text { Extreme } \\
\text { drought }\end{array}$ & SPEI-24 $\leq-1.5$ & Prec $\leq P_{10}$ \\
\hline $\begin{array}{c}\text { Severe } \\
\text { drought }\end{array}$ & $-1.5<$ SPEI-24 $\leq-1.0$ & $P_{10}<$ Prec $\leq P_{20}$ \\
\hline $\begin{array}{c}\text { Moderate } \\
\text { drought }\end{array}$ & $-1.0<$ SPEI-24 $\leq-0.5$ & $P_{20}<$ Prec $\leq P_{30}$ \\
\hline Normal & $-0.5<$ SPEI-24 $<0.5$ & $P_{30}<$ Prec $\leq P_{70}$ \\
\hline $\begin{array}{c}\text { Moderately } \\
\text { wet }\end{array}$ & $0.5 \leq$ SPEI-24 $<1.0$ & $P_{70}<$ Prec $\leq P_{80}$ \\
\hline Severely wet & $1.0 \leq$ SPEI-24 $<1.5$ & $P_{80}<$ Prec $\leq P_{90}$ \\
\hline $\begin{array}{c}\text { Extremely } \\
\text { wet }\end{array}$ & SPEI-24 $\geq 1.5$ & Prec $>P_{90}$ \\
\hline
\end{tabular}


Table 2. Detection of ST of drought indicators, applying the Mann-Kendall statistic.

\begin{tabular}{|c|c|c|c|c|c|c|c|}
\hline \multicolumn{4}{|c|}{ Location } & \multicolumn{4}{|c|}{$\begin{array}{c}\text { Standardized } Z\left(Z_{\text {stt }}\right) \text { with } \alpha=0.05 \text {. threshold. } \\
\quad Z=\geq 1.96 \text { (dimensionless) }\end{array}$} \\
\hline State & Weather station & $\begin{array}{c}E \\
\text { (masl) }\end{array}$ & $\begin{array}{c}P_{a} \\
\left(\mathrm{~mm} \cdot \mathrm{yr}^{-1}\right)\end{array}$ & $T_{\text {avg }}$ & Prec & PET & SPEI-24 \\
\hline \multirow{13}{*}{ Sinaloa } & Acatitan & 130 & 627 & 3.38 & 1.79 & -3.45 & 3.70 \\
\hline & Culiacan & 40 & 569 & 0.18 & -0.11 & 0.34 & 3.89 \\
\hline & El Playon & 5 & 345 & -4.07 & -3.56 & -4.28 & -4.13 \\
\hline & Guasave & 40 & 341 & -0.01 & 0.62 & -1.17 & 3.44 \\
\hline & Guatenipa & 18 & 801 & -5.28 & 0.87 & -5.28 & 3.46 \\
\hline & Jaina & 200 & 703 & -5.33 & 0.54 & -5.41 & 2.18 \\
\hline & Palmar de Los S. & 21 & 489 & 0.70 & -0.91 & -0.33 & -1.41 \\
\hline & Pericos & 11 & 507 & -2.72 & 2.65 & -2.70 & 1.98 \\
\hline & Ruiz Cortinez & 15 & 261 & -4.17 & 1.72 & -4.32 & 3.70 \\
\hline & Santa Cruz & 2050 & 590 & -4.18 & 0.96 & -4.23 & 2.40 \\
\hline & Siqueros & 12 & 537 & -2.75 & 1.32 & -2.67 & -3.44 \\
\hline & Surutato & 1400 & 765 & -0.81 & 2.12 & -1.35 & 2.16 \\
\hline & Topolobampo & 34 & 221 & 2.55 & 0.25 & 3.38 & 1.86 \\
\hline \multirow{16}{*}{ Baja California Sur } & Caduaco & 206 & 333 & -1.05 & 4.06 & -1.02 & 1.61 \\
\hline & Constitución & 47 & 101 & -1.39 & -0.5 & -1.31 & -1.96 \\
\hline & El Paso de Iritu & 135 & 134 & -1.04 & 1.84 & -1.14 & -2.02 \\
\hline & El Refugio & 23 & 40 & -1.39 & 2.32 & -1.31 & -2.63 \\
\hline & El Rosario & 45 & 71 & -3.31 & -0.52 & -3.25 & -4.67 \\
\hline & $\mathrm{La} \mathrm{Paz}$ & 16 & 115 & 0.35 & 0.78 & 0.29 & -3.44 \\
\hline & La Poza Grande & 25 & 24 & 0.54 & 0.69 & 0.44 & -4.19 \\
\hline & La Purísima & 95 & 57 & -1.58 & 0.41 & -1.57 & 2.12 \\
\hline & La Soledad & 412 & 187 & 0.42 & 1.25 & 0.70 & -2.76 \\
\hline & Las Cruces & 40 & 72 & -0.83 & 0.87 & 0.90 & -1.86 \\
\hline & Ligui & 10 & 143 & -2.05 & 1.67 & -1.41 & 2.46 \\
\hline & Los Divisaderos & 502 & 316 & -0.87 & 1.69 & 0.87 & -2.52 \\
\hline & Penjamo & 24 & 75 & -0.45 & -0.88 & -0.44 & -3.55 \\
\hline & Puerto San Carlos & 10 & 32 & -3.73 & 1.12 & -4.16 & -2.40 \\
\hline & San Javier & 440 & 206 & 1.40 & 0.90 & 1.38 & 1.98 \\
\hline & Todos Santos & 75 & 104 & -5.97 & 1.13 & -5.83 & 1.72 \\
\hline \multirow{6}{*}{ Durango } & Huahuapan & 1150 & 608 & -1.97 & 0.19 & -2.69 & 1.31 \\
\hline & Ojito de Camellones & 15 & 1039 & -1.14 & 2.34 & -1.16 & 0.08 \\
\hline & Pena de Águila & 1896 & 438 & -5.13 & 0.70 & -5.18 & 2.31 \\
\hline & San Miguel de Lobos & 2300 & 605 & 2.50 & -0.88 & 2.49 & 2.12 \\
\hline & Santiago Papasquiaro & 1716 & 418 & 2.80 & 4.17 & 2.76 & 0.86 \\
\hline & Tamazula & 1580 & 778 & 1.17 & 0.65 & 1.16 & 1.94 \\
\hline \multirow{2}{*}{ Chihuahua } & El Tarahumar & 2435 & 617 & 1.24 & -0.11 & 1.23 & 0.90 \\
\hline & Guerachic & 780 & 125 & -0.18 & 1.69 & -0.61 & 2.16 \\
\hline Sonora & Don Huatabampo & 50 & 325 & 2.00 & -1.42 & 1.15 & 2.67 \\
\hline
\end{tabular}

$E=$ elevation. $P_{a}=$ cumulative annual average of precipitation. $T_{a v g}=$ average seasonal temperature. Prec $=$ cumulative annual average seasonal precipitation. $P E T=$ seasonal potencial evapotranspiration. $S P E I-24=$ Standardized Precipitation Evapotranspiratoion Index. Bold $=$ significant trend indicators 
weather stations chosen for this study was that only these 38 stations out of a total of 56 met the requirement of a minimum percentage of daily data $(\geq 95 \%)$ used for calculating $T_{a v g}$ and Prec. Of the 38 stations, 13 are located in SIN (population 2,767,761), 16 in BCS $(637,026), 6$ in DGO $(1,632,934), 2$ in CHIH $(3,406,465)$, and 1 in SON $(2,662,480)$ [28]. The range of $E$ among the stations by state was 5 to 2,050 masl for SIN, 10 to 502 masl for $\mathrm{BCS}, 15$ to 2,300 masl for $\mathrm{DGO}, 780$ to 2,435 masl for
$\mathrm{CHIH}$, and 50 masl for the single station in SON. With the exception of DGO, the states in the study border mountainous zones (Sierra Madre Occidental) and the Gulf of California [29] (Fig. 1).

\section{Identification and Quantification of $S T$}

To detect, estimate, and quantify the trends in the time series of average annual $T_{\text {avg }}$, Prec, PET, and SPEI-24,

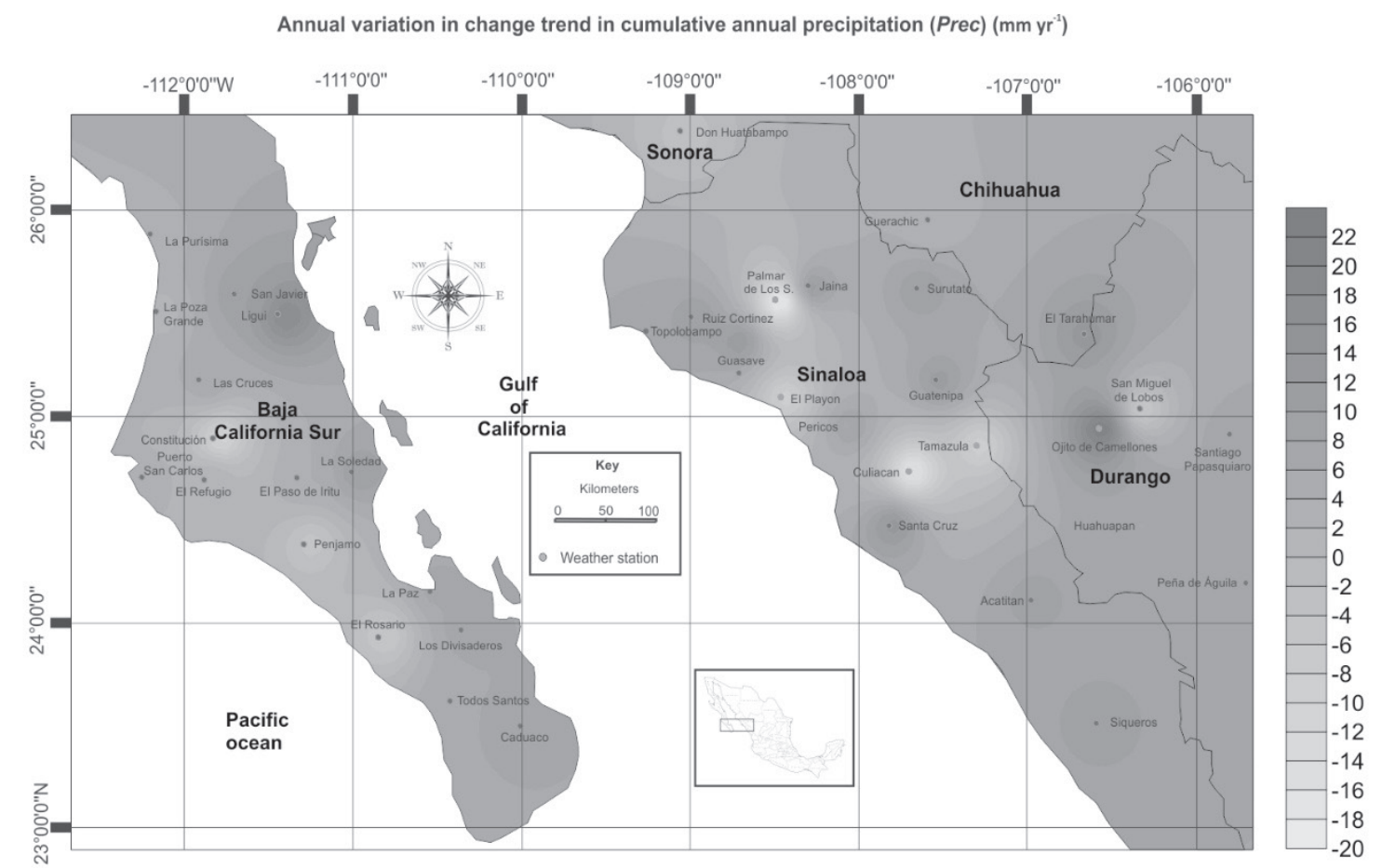

Variation in cumulative annual precipitation trends by weather station (Prec, $\left.\mathrm{mm}^{-1} \mathrm{yr}^{-1}\right)$
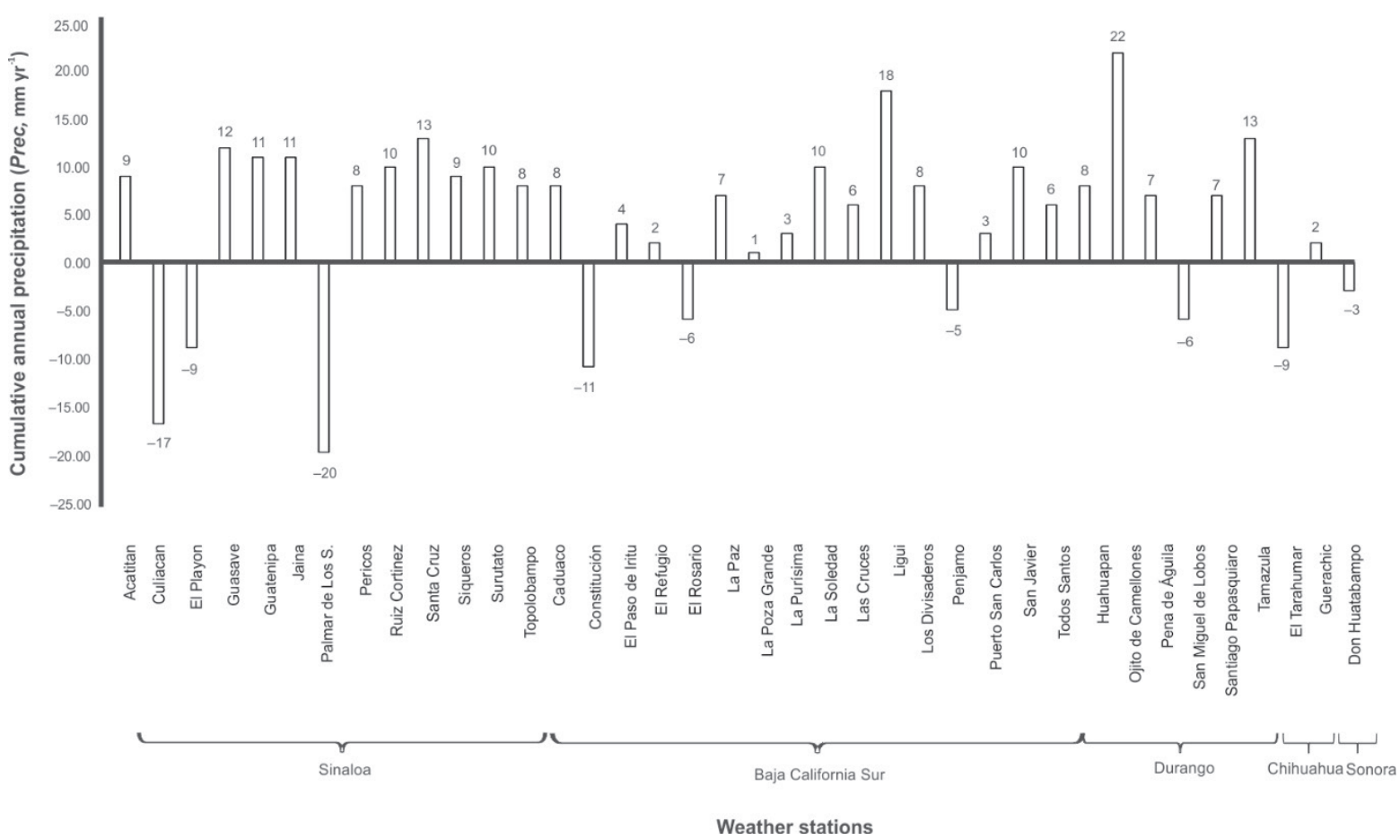

Fig. 2. Magnitude of change trends in Prec in states in northern Mexico $\left(\mathrm{mm} \mathrm{yr}^{-1}\right)$. 
we used the non-parametric methods of Mann-Kendall [20] and Sen's slope estimate [21]. These methods have been effective for detecting, estimating, and quantifying annual averages in trends in atmospheric data, drinking water quality, agricultural irrigation, and concentration of pollutants in the atmosphere, among others [20,30]. According to [31], for correct analysis of $S T$ in time series of thermopluviographic data, the data must be continuous ( $\geq 30$ years). The CONAGUA time series data used in this study meet this condition. In order to detect $S T$, the Mann-Kendall test [20, 32-33] was applied. The statistical threshold $\left(Z_{s t d}\right)$ for a $95 \%$ confidence interval was $\geq$ I1.96I. The null hypothesis was rejected at the $\alpha=0.05$ level of significance. A positive value of $Z_{\text {std }}$ indicated a $P T$ and a negative value indicated an NT in the data [34]. The magnitude of each trend was estimated using Sen's slope estimator [18] from among the possible slopes that can be calculated for a time series $[31,35]$.

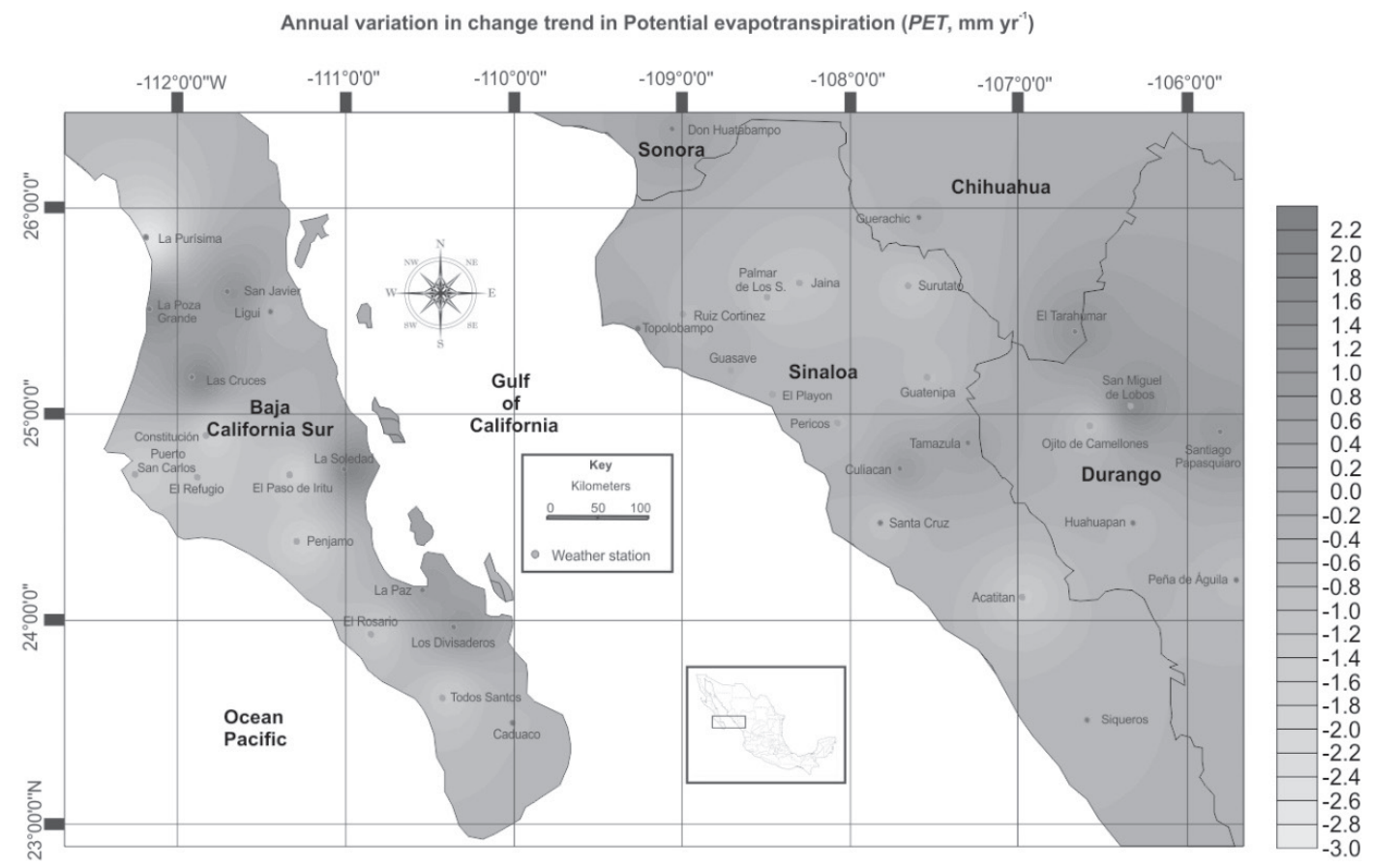

Variation in Potential evapotranspiration (PET, $\left.\mathrm{mm} \mathrm{yr}^{-1}\right)$

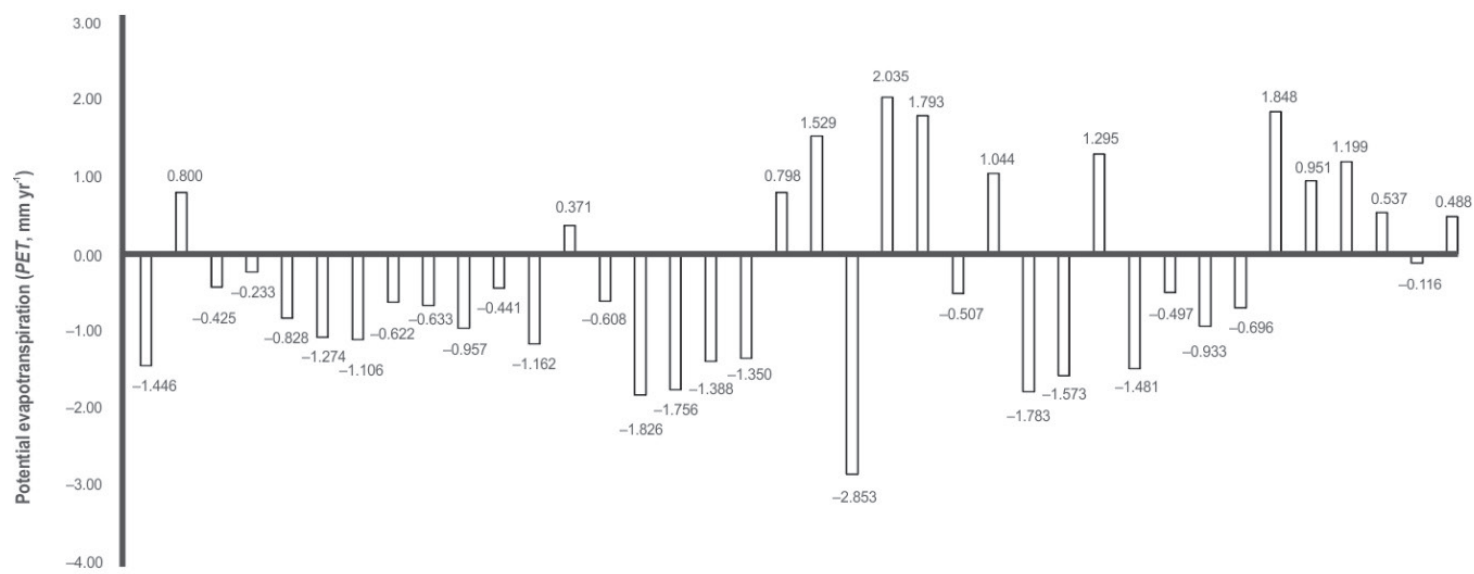

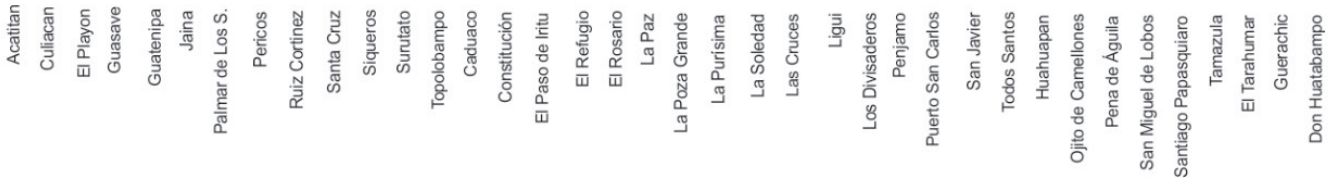

$$
\begin{aligned}
& \underbrace{\underbrace{}_{\text {Baja California Sur }}}_{\text {Sinaloa }} \underbrace{\underbrace{}_{\text {Chihuahua Sonora }}}_{\text {Durango }}
\end{aligned}
$$

Fig. 3. Magnitude of change trends in PET in states in northern Mexico $\left(\mathrm{mm} \mathrm{yr}^{-1}\right)$. 
Table 3 Quantification of magnitude of change of ST of drought indicators, using Sen's slope estimator.

\begin{tabular}{|c|c|c|c|c|c|}
\hline \multicolumn{2}{|c|}{ Location } & \multicolumn{4}{|c|}{ Magnitude of change trend indicator } \\
\hline State & Weather station & $\begin{array}{c}T_{a v g} \\
\left({ }^{\circ} \mathrm{C} \cdot \mathrm{yr}^{-1}\right)\end{array}$ & $\begin{array}{c}\text { Prec } \\
\left(\mathrm{mm} \cdot \mathrm{yr}^{-1}\right)\end{array}$ & $\begin{array}{c}P E T \\
\left(\mathrm{~mm} \cdot \mathrm{yr}^{-1}\right)\end{array}$ & $\begin{array}{c}\text { SPEI-24 } \\
\text { (Dimensionless) }\end{array}$ \\
\hline \multirow{13}{*}{ Sinaloa } & Acatitan & $-0,090$ & 9 & $-1,446$ & $\mathbf{0 , 0 5 3}$ \\
\hline & Culiacan & 0,049 & -17 & 0,800 & 0,082 \\
\hline & El Playon & $-0,026$ & -9 & $-0,425$ & $-0,065$ \\
\hline & Guasave & 0,099 & 12 & $-0,233$ & 0,056 \\
\hline & Guatenipa & $-0,049$ & 11 & $-0,828$ & 0,063 \\
\hline & Jaina & $-0,065$ & 11 & $-1,074$ & 0,062 \\
\hline & Palmar de Los S. & 0,068 & -20 & $-1,106$ & $-0,069$ \\
\hline & Pericos & $-0,040$ & 8 & $-0,622$ & 0,055 \\
\hline & Ruiz Cortinez & $-0,049$ & 10 & $-0,663$ & 0,063 \\
\hline & Santa Cruz & $-0,059$ & 13 & $-0,957$ & $\mathbf{0 , 0 5 7}$ \\
\hline & Siqueros & $-0,028$ & 9 & $-0,441$ & $-0,048$ \\
\hline & Surutato & $-0,058$ & 10 & $-1,162$ & 0,067 \\
\hline & Topolobampo & 0,061 & 8 & 0,371 & 0,056 \\
\hline \multirow{16}{*}{ Baja California Sur } & Caduaco & $-0,124$ & 8 & $-0,608$ & 0,049 \\
\hline & Constitución & $-0,109$ & -11 & $-1,826$ & $-0,050$ \\
\hline & El Paso de Iritu & $-0,103$ & 4 & $-1,756$ & $-0,053$ \\
\hline & El Refugio & $-0,082$ & 2 & $-1,388$ & $-0,046$ \\
\hline & El Rosario & $-0,079$ & -6 & $-1,350$ & $-0,056$ \\
\hline & La Paz & 0,048 & 7 & 0,798 & $-0,062$ \\
\hline & La Poza Grande & 0,093 & 1 & 1,529 & $-0,066$ \\
\hline & La Purísima & $-0,174$ & 3 & $-2,853$ & 0,060 \\
\hline & La Soledad & 0,130 & 10 & 2,035 & $-0,058$ \\
\hline & Las Cruces & $-0,101$ & 6 & 1,793 & $-0,050$ \\
\hline & Ligui & $-0,057$ & 18 & $-0,507$ & 0,061 \\
\hline & Los Divisaderos & $-0,064$ & 8 & 1,044 & $-0,059$ \\
\hline & Penjamo & $-0,107$ & -5 & $-1,783$ & $-0,062$ \\
\hline & Puerto San Carlos & $-0,133$ & 3 & $-1,573$ & $-0,046$ \\
\hline & San Javier & 0,080 & 10 & 1,295 & 0,059 \\
\hline & Todos Santos & $-0,090$ & 6 & $-1,481$ & 0,060 \\
\hline \multirow{6}{*}{ Durango } & Huahuapan & $-0,026$ & 8 & $-0,497$ & 0,047 \\
\hline & Ojito de Camellones & $-0,046$ & 22 & -0.933 & 0,060 \\
\hline & Pena de Águila & $-0,034$ & 7 & $-0,696$ & 0,044 \\
\hline & San Miguel de Lobos & 0,076 & -6 & 1,848 & 0,054 \\
\hline & Santiago Papasquiaro & 0,049 & 7 & 0,951 & 0,040 \\
\hline & Tamazula & 0,061 & 13 & 1,199 & 0,058 \\
\hline \multirow{2}{*}{ Chihuahua } & El Tarahumar & 0,032 & -9 & 0,537 & 0,050 \\
\hline & Guerachic & $-0,042$ & 2 & $-0,116$ & 0,054 \\
\hline Sonora & Don Huatabampo & 0,106 & -3 & 0,488 & 0,062 \\
\hline
\end{tabular}

$T_{a v g}=$ average seasonal temperature, Prec $=$ cumulative annual average seasonal precipitation, $P E T=$ seasonal potencial evapotranspiration, SPEI-24 = Standardized Precipitation Evapotranspiratoion Index, Bold $=$ significant trend indicators 
Table 4. Time scales of RP of seasonal drought associated with deciles 1, 2, 3, 7, 8 and 9 of Prec in northern Mexico.

\begin{tabular}{|c|c|c|c|c|c|c|c|c|}
\hline $\begin{array}{l}\text { Return periods } \\
\text { (years) }\end{array}$ & $\begin{array}{c}\text { Probability } \\
\text { (dimensionless) }\end{array}$ & State & $P_{10}$ & $P_{20}$ & $P_{30}$ & $P_{70}$ & $P_{80}$ & $P_{90}$ \\
\hline 2 & 0.5 & Sinaloa & 0.93 & 1.78 & 2.95 & 15.50 & 23.38 & 32.63 \\
\hline 5 & 0.8 & Baja California Sur & 1.33 & 2.55 & 3.75 & 15.75 & 24.26 & 41.48 \\
\hline 10 & 0.9 & Durango & 1.80 & 2.00 & 3.14 & 9.46 & 12.00 & 19.34 \\
\hline 25 & 0.96 & Chihuahua & 0.84 & 1.40 & 2.30 & 9.78 & 14.60 & 19.48 \\
\hline 50 & 0.98 & Sonora & 0.50 & 1.50 & 2.50 & 20.00 & 26.00 & 52.00 \\
\hline 100 & 0,99 & & & & & & & \\
\hline 200 & 0,995 & & & & & & & \\
\hline 500 & 0,998 & & & & & & & \\
\hline
\end{tabular}
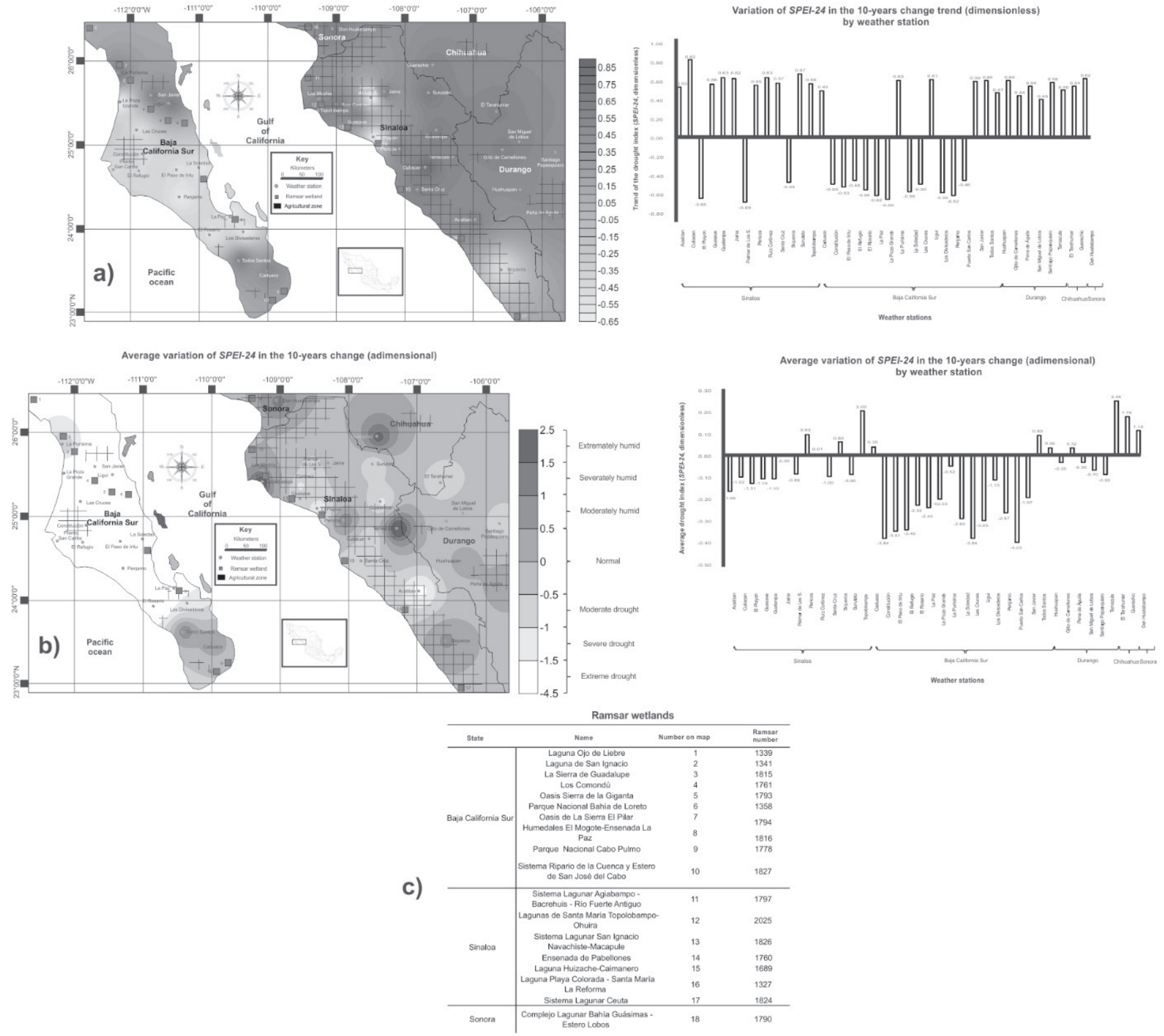

Fig. 4. Seasonal variation of SPEI-24: a) variation in the 10-year change trend (dimensionless), b) average variation in 10-year change (dimensionless), and c) Ramsar wetlands in northern Mexico. 


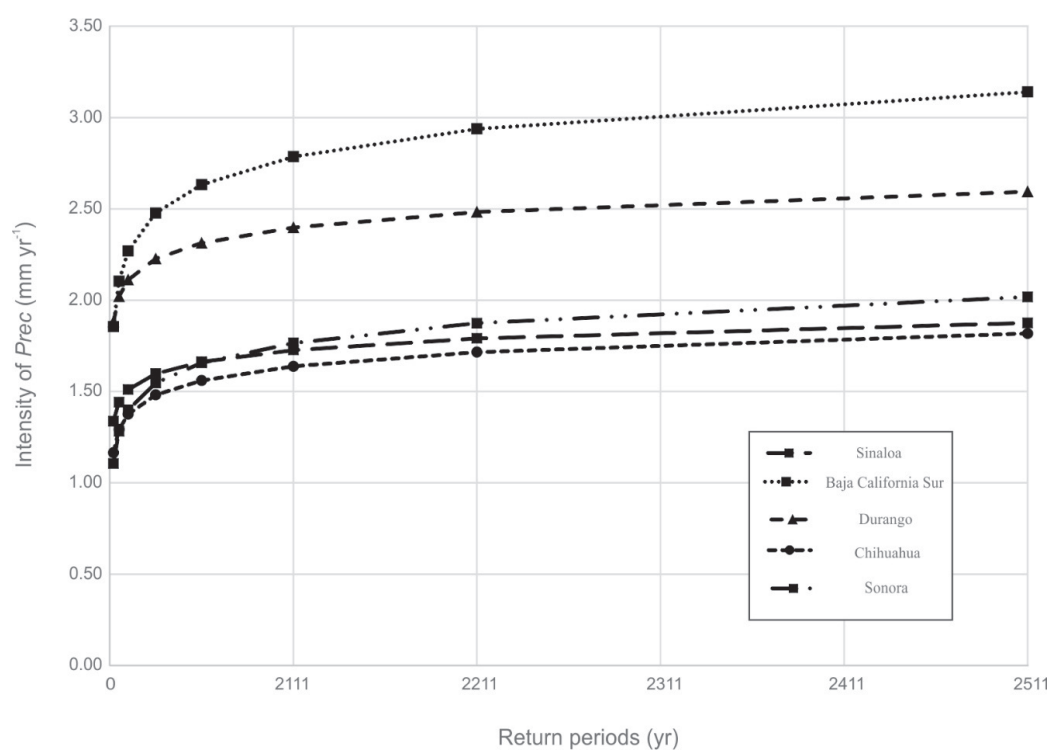

Fig. 5. Intensity of $R P$ of droughts in northern Mexico, using time scales of 2, 5, 10, 25, 50, 100, 200 and 500 years.

\section{Calculation of PET and the SPEI-24 Index}

To obtain SPEI-24 and PET, the expression of Serrano [7] and the relationship of Thornthwaite [19], respectively, were applied. The expression for SPEI-24 calculates drought based on the variation of Prec and PET. From daily $T_{a v g}$ and Prec data, monthly and annual time series were constructed for $T_{\text {avg }}$, Prec, PET, and SPEI-24; and the annual series was used to calculate the averages of $T_{\text {avg }}$, Prec, PET, and SPEI-24 and the cumulative annual average value for Prec $\left(P_{a}\right)$. To classify seasonal drought in northern Mexico we applied the categorization of [22], which relates the variation of SPEI-24 to deciles $1,2,3,7$, 8, and 9 of Prec (Table 1, Fig. 3).

\section{Generating Trend Maps}

The $I D W$ method included in the Surfer 10.0 software was used to interpolate the seasonal magnitudes of $S T$ for each weather station. This deterministic interpolation method is one of the most common methods for constructing maps containing spatial information of climate indicators [36]. However, the $I D W$ has the disadvantage that it tends to generate closed surfaces around the data when the power coefficient $(P)$ is small. To avoid this, in this paper the criterion of [18] for a coefficient of $P=2$ was used to generate continuous smooth surfaces. The results of the $I D W$ interpolation were applied to the urban trace drawn using CorelDRAW X7 (Fig. 1). To visualize important spatial changes in the interpolation maps, the magnitudes of annual spatial variation of $S T$ in $T_{a v g}$ and SPEI-24 were multiplied by 10 in order to convert magnitudes of spatial variation of $S T$ to a decadal time scale.

\section{Return Periods of Droughts}

By means of the seasonal deciles 1, 2, 3, 7, 8, and 9 of Prec and the probability distribution function of
Gumbel, the $R P$ of droughts were calculated for each state in the study on 2-, 5-, 10-, 25-, 50-, 100-, 200-, and 500year time scales (Tables 1, 4, Fig. 5). According to [23, 37], the Gumbel probability distribution function is the distribution most recommended for frequency analysis against extreme values because of its high statistical reliability in hydrology [38].

\section{Statistical Analysis}

Spearman correlation coefficients $(S r)$ were calculated between the trend groups of $T_{\text {avg }}$ and Prec $\left(T_{\text {avgcal }}\right.$ and Prec $_{\text {avgcal }}$ ) obtained from CONAGUA weather stations, and the data obtained from weather stations $\left(T_{\text {avgobs }}\right.$ and Prec $_{\text {avgobs }}$ ) for 1970-2011 [39]. This method was used because it is the most common method for non-normal data [40]. Before calculating $S r$, the Shapiro-Wilk normality test was applied to the four groups in the data series. This test statistic was employed mainly because it shows good power for small $n(n<50)$ [41]. The PAleontological STatistics (PAST) program (v. 3.14) [42] and Microsoft Excel version 2013 were used for all data processing and calculation of test statistics.

\section{Results and Discussion}

Table 2 shows the spatial variation in $S T$ of $T_{\text {avg }}$, Prec, $P E T$, and SPEI-24, according to the Mann-Kendall statistic $(\alpha=0.05)$. $S T$ for $T_{\text {avg }}$ was observed at 18 stations (four with $P T$ and 14 with NT). The stations with the largest $N T$ were Puerto San Carlos $\left(-0.133^{\circ} \mathrm{C} \mathrm{yr}^{-1}\right)$ and El Rosario $\left(-0.079^{\circ} \mathrm{C} \mathrm{yr}^{-1}\right)$ in $\mathrm{BCS}$. The largest magnitudes of $P T$ were observed at Don Huatabampo $\left(0.106^{\circ} \mathrm{C} \mathrm{yr}^{-1}\right)$ in SON and San Miguel de Lobos $\left(0.076^{\circ} \mathrm{C} \mathrm{yr}^{-1}\right)$ in DGO. Average $N T$ was $T_{a v g}=-0.059^{\circ} \mathrm{C} \mathrm{yr}^{-1}\left(-0.59^{\circ} \mathrm{C}\right.$ decade $\left.^{-1}\right)$ and $P T$ $T_{\text {avg }}=0.073^{\circ} \mathrm{C} \mathrm{yr}^{-1}\left(0.73^{\circ} \mathrm{C} \mathrm{decade}^{-1}\right)$ (Tables 2-3, Fig. 1). Without taking into account the $S T$ of $P T$, the average was $T_{\text {avg }}=0.073^{\circ} \mathrm{C} \mathrm{yr}^{-1}$, which differs from the results obtained 
Table 5. Observed and calculated annual trends of $T_{\text {avg }}\left({ }^{\circ} \mathrm{C} \mathrm{yr}^{-1}\right)$ and $\mathrm{Prec}\left(\mathrm{mm} \mathrm{yr}^{-1}\right)$ at weather stations in northern Mexico.

\begin{tabular}{|c|c|c|c|c|c|}
\hline & & \multicolumn{4}{|c|}{ Trends } \\
\hline \multirow{2}{*}{ State } & \multirow{2}{*}{ Weather station } & \multicolumn{2}{|c|}{$T_{a v g}$} & \multicolumn{2}{|c|}{ Prec } \\
\hline & & Obs & $\mathrm{Cal}$ & Obs & $\mathrm{Cal}$ \\
\hline \multirow{13}{*}{ Sinaloa } & Acatitan & -0.060 & -0.090 & 12 & 9 \\
\hline & Culiacan & 0.071 & 0.049 & -15 & -17 \\
\hline & El Playon & -0.045 & -0.026 & -5 & -9 \\
\hline & Guasave & 0.061 & 0.099 & 15 & 12 \\
\hline & Guatenipa & -0.075 & -0.049 & 5 & 11 \\
\hline & Jaina & -0.085 & -0.065 & 16 & 11 \\
\hline & Palmar de Los S. & 0.029 & 0.068 & -24 & -20 \\
\hline & Pericos & -0.040 & -0.040 & 4 & 8 \\
\hline & Ruiz Cortinez & -0.084 & -0.049 & 10 & 10 \\
\hline & Santa Cruz & -0.091 & -0.059 & 16 & 13 \\
\hline & Siqueros & -0.059 & -0.028 & 13 & 9 \\
\hline & Surutato & -0.080 & $\mathbf{- 0 . 0 5 8}$ & 9 & 10 \\
\hline & Topolobampo & 0.111 & 0.061 & 14 & 8 \\
\hline \multirow{16}{*}{$\begin{array}{c}\text { Baja } \\
\text { California Sur }\end{array}$} & Caduaco & -0.184 & -0.124 & 10 & 8 \\
\hline & Constitución & -0.108 & -0.109 & -8 & -11 \\
\hline & El Paso de Iritu & -0.133 & -0.103 & 8 & 4 \\
\hline & El Refugio & -0.085 & -0.082 & 9 & 2 \\
\hline & El Rosario & -0.104 & -0.079 & -15 & -6 \\
\hline & $\mathrm{LaPaz}$ & 0.060 & 0.048 & 7 & 7 \\
\hline & La Poza Grande & 0.110 & 0.093 & 6 & 1 \\
\hline & La Purísima & 0.142 & 0.174 & 8 & 3 \\
\hline & La Soledad & 0.110 & 0.130 & 7 & 10 \\
\hline & Las Cruces & -0.086 & -0.101 & 9 & 6 \\
\hline & Ligui & -0.039 & $-\mathbf{0 . 0 5 7}$ & 15 & 18 \\
\hline & Los Divisaderos & -0.046 & -0.064 & 5 & 8 \\
\hline & Penjamo & -0.079 & -0.107 & -15 & -5 \\
\hline & Puerto San Carlos & -0.083 & -0.133 & 8 & 3 \\
\hline & San Javier & 0.084 & 0.080 & 14 & 10 \\
\hline & Todos Santos & -0.075 & -0.090 & 10 & 6 \\
\hline \multirow{6}{*}{ Durango } & Huahuapan & -0.020 & -0.026 & 6 & 8 \\
\hline & Ojito de Camellones & -0.030 & -0.046 & 26 & 22 \\
\hline & Peña de Águila & -0.015 & -0.034 & 12 & 7 \\
\hline & San Miguel de Lobos & 0.055 & 0.076 & -5 & -6 \\
\hline & Santiago Papasquiaro & 0.050 & 0.049 & 10 & 7 \\
\hline & Tamazula & 0.038 & 0.061 & 11 & 13 \\
\hline \multirow{2}{*}{ Chihuahua } & El Tarahumar & 0.056 & 0.032 & -15 & -9 \\
\hline & Guerachic & -0.030 & -0.042 & 6 & 2 \\
\hline Sonora & Don Huatabampo & 0.141 & 0.106 & -8 & -3 \\
\hline
\end{tabular}

$T_{a v g}=$ average seasonal temperature, Prec $=$ cumulative annual average seasonal precipitation, Obs = observed value, $\mathrm{Cal}=$ calculated value and bold $=$ significant trends . 
by IPCC (2013) over the period 1906-2005, in which the $P T$ was $T_{a v g}=0.74^{\circ} \mathrm{C}\left(0.56-0.92^{\circ} \mathrm{C}\right)$. The $P T$ of $T_{a v g}$ was associated with an increase in the frequency and intensity of frost, which affected crop and livestock yield and profit, causing considerable economic losses to vegetable, fruit, flower, potato, maize, and feed production. The local population depends on these and other agricultural products for both food and income [43]. Fig. 2 shows the PT and NT of Prec.

The zones with the highest variability are in the north of BCS at the Constitución and Ligui stations. This is attributed to homogeneous climate changes and the high variability of $T_{\text {avg }}$. ST were observed at only five stations (four $P T$ and one NT), of which Ojito de Camellones in DGO (22 $\left.\mathrm{mm} \mathrm{yr}^{-1}\right)$ was the station with highest magnitude of $P T$ and El Playon in SIN (-9 $\left.\mathrm{mm} \mathrm{yr}^{-1}\right)$ the station with the greatest NT. The $S T$ of Prec are less significant than those of temperature. The average Prec $=9.75 \mathrm{~mm} \mathrm{yr}^{-1}$ for $P T$, and the overall average (all trends) of Prec $=4.21 \mathrm{~mm} \mathrm{yr}^{-1}$ (Table 3 and Fig. 2). The $S T$ results for Prec are very similar to those reported by [1], which report no evident trends in $P_{a}$, and that worldwide $T_{a v g}$ increased $0.85^{\circ} \mathrm{C}$ from 1880 to 2012 [44]. ST of PET were observed at 16 stations (13 with NT and three

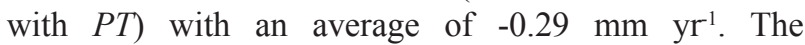
stations with the most extreme $P T$ were San Miguel de Lobos (1.848 $\left.\mathrm{mm} \mathrm{yr}^{-1}\right)$ and Santiago Papasquiaro $\left(0.951 \mathrm{~mm} \mathrm{yr}^{-1}\right)$ in DGO; and the stations with the greatest magnitude of NT were in BCS; Puerto San Carlos $\left(-1.573 \mathrm{~mm} \mathrm{yr}^{-1}\right)$ and Todos Santos $\left(-1.481 \mathrm{~mm} \mathrm{yr}^{-1}\right)$. The results for PET are consistent with those reported by [45] in Spain and Portugal in the period 1970-2010, where they state that the annual seasonal PET mean was $3.1 \mathrm{~mm} \mathrm{yr}^{-1}$. The results of this study also agree with the findings of [46], where the average trend of PET in China for the period 1960-2013 was $-2.92 \mathrm{~mm}(10 \mathrm{~km})^{-1}$.

For the SPEI-24, ST were observed at 28 stations (13 with $N T$ and 15 with $P T)$. The highest values of $P T$ were at Culiacán (0.082) and Surutato (0.067) in SIN, and the greatest magnitudes of $N T$ were recorded at La Poza Grande (-0.066) in BCS and El Playon (-0.065) in SIN. Considering only the $S T$, the average of $N T=-0.056$ and $P T=0.060$. Without taking into consideration $\alpha=0.05$, the average was 0.015 (Tables 1-2, Fig. 4). The results of SPEI-24 agree with [9], who found that the trends of annual Prec and SPEI in China are related to changes in $T_{\text {avg }}$ and $P E T$ trends. No published records of the SPEI index for northern Mexico were found; however, CONAGUA [47] reported variations in the Standardized Precipitation Index (SPI), which averaged 0.011 for the period 1970-2011.

Knowledge of ST in SPEI-24 can be used in development of adaptation and mitigation measures such as construction designed to withstand extreme temperatures and precipitation, design of droughtresistant seeds, or water rationing for agriculture, among other measures [39]. The $S T$ of $T_{\text {avg }}$ and PET recorded in Guasave (Fig. 4a) should serve to stimulate actions taken to mitigate and adapt to climate change. These $S T$ in Guasave could be the main factor that explains the
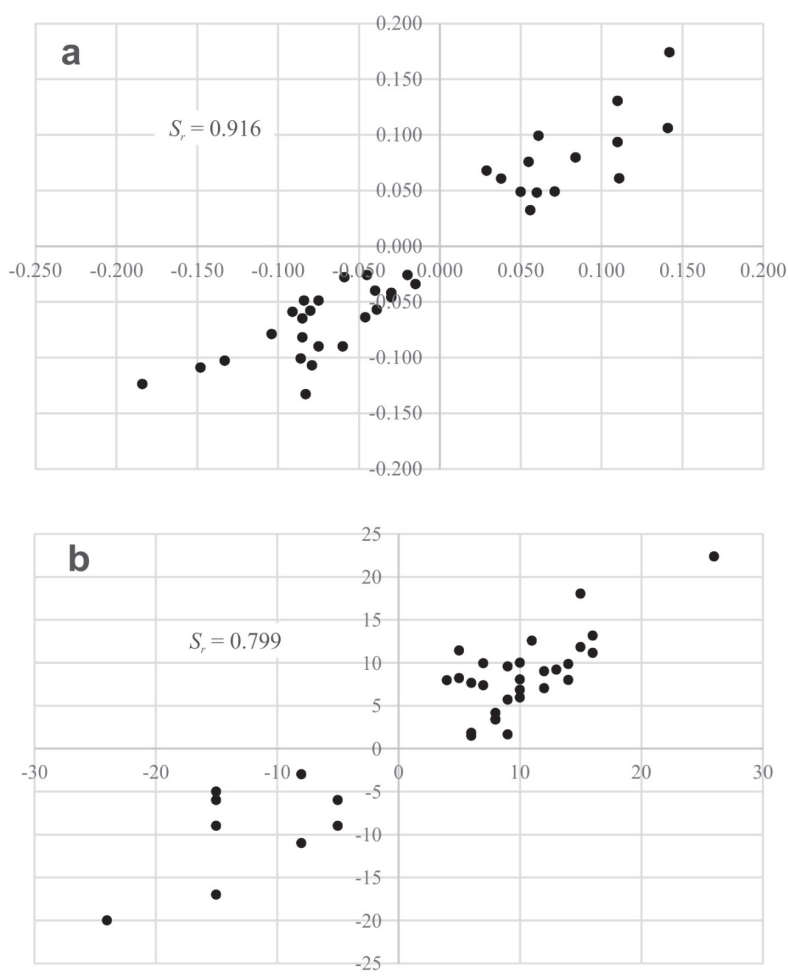

Fig. 6. Dispersion of observed and calculated data of: a) $T_{\text {avg }}\left({ }^{\circ} \mathrm{C}\right.$ $\left.\mathrm{yr}^{-1}\right)$ and b) Prec $\left(\mathrm{mm} \mathrm{yr}^{-1}\right)$ by weather station in northern Mexico.

hysteresis of variability in agricultural production and soil damage due to temperature increase, which affects food security at local and international levels [48]. The areas adjacent to El Playón in SIN are important because they are vulnerable to $N T$ in $T_{\text {avg }}$, Prec, PET, and SPEI-24, and this station is located near Ramsar wetlands 13 and 14 (Lagunar San Ignacio Navachiste-Macapule System and Ensenada de Pabellones, respectively). The Siqueros station in SIN and Constitución in BCS showed $S T$ in SPEI-24; these stations are located near Ramsar wetlands 16 , and 4, 5, and 6, respectively (Laguna Playa ColoradaSanta María La Reforma and Los Comondú, Oasis Sierra de La Giganta and Loreto Bay National Park), which are among the most important ecosystems and the most threatened by drought at the worldwide level (Fig. 4) [49]. The observed range in SPEI-24 showed that the drought category varied from extreme drought to extremely wet, with values from -3.37 (Pericos) to 2.56 (Jaina) in SIN, from -2.25 (La Poza Grande) to 2.31 (Todos Santos) in BCS, from -2.71 (Huahuapan) to 2.23 (Tamazula) in DGO, from -1.67 (Guerachic) to 2.25 (El Tarahumar) in $\mathrm{CHIH}$, and from -1.85 to 2.26 in the only station analyzed in SON (Don Huatabampo) (Fig. 4a). The annual averages for SPEI-24 were -0.04 in SIN, -0.23 in BCS, -0.028 in DGO, 0.21 in CHIH, and 0.11 in SON (Fig. 4b).

\section{Return Periods of Droughts}

Table 4 and Fig. 5 show the $R P$ of drought associated with deciles $1,2,3,7,8$, and 9 in the study area in northern 
Mexico. According to the results in BCS and SIN, there will be severe droughts in 2021 and 2036 (Tables 1, 4, Fig. 5). It is important to develop adaptation and mitigation plans prior to the occurrence of severe droughts in order to ensure food sustainability at the national and international levels [50]. The results of this work are similar to those reported for China by [51], who predict that there will be droughts in 2015.6 and 2020.5. Fig. 5 shows the $R P$ of drought according to the intervals of variation of deciles 1, 2, 3, 7, 8, and 9 of Prec for each study state in northern Mexico. According to Tables 1 and 4, and Fig. 5, the states pf DGO, CHIH, and SON will not experience extreme droughts, although they will experience moderate drought events in 2036, 2061, 2111, 2211, and 2511 .

\section{Statistical Analysis}

The four groups of data $\left(T_{\text {avgobs }}, T_{\text {avgca }} 1\right.$, Prec ${ }_{\text {obs }}$, and Prec $_{\text {cal }}$ ) did not show normality: respectively, $\mathrm{p}$ $($ normal $)=0.037, \mathrm{p}($ normal $)=0.019, \mathrm{p}($ normal $)=0.001$, and $\mathrm{p}$ (normal) $=0.012$, and $\mathrm{W}=0.9385, \mathrm{~W}=0.9295$, $\mathrm{W}=0.8789$, and $\mathrm{W}=0.9229$ (Table 5). The correlation coefficient $S_{r}$ for $T_{a v g}$ was $S_{r}=0.916$; P (uncorr) = $6.91 \times 10^{-16}$ and for Prec, $S_{r}=0.799 ; \mathrm{P}$ (uncorr) $=1.82 \times 10^{-9}$ (Table 5, Figs 6a-b).

\section{Conclusions}

An important finding of this study is the behavior of $T_{a v g}$ with $S T$ at the stations of Topolobampo, Puerto San Carlos, and Todos Santos, which are near international tourism destinations. Tourism strategies for adaptating to climate change must be implemented to avoid respiratory, gastrointestinal or cutaneous diseases due to abrupt changes of $T_{\text {avg }}$. The few ST of Prec may be associated with tropical cyclones. The core North American monsoon region, constituted by SIN, SON, and $\mathrm{CHIH}$, is vulnerable to the effect of $S T$ in Prec associated with tropical cyclones [18]. The excess rainfall associated with these events can severely affect soil in the form of water erosion and disaggregation by torrential rains [49].

The $S T$ found by this study can help soil management analyses accurately incorporate the impact of tropical storm events on local agriculture. These results require environmental conservation and adaptation of Ramsar wetlands, and tourist and agricultural areas that sustain local and national economies. We recommend reforesting the Ramsar wetlands, which according to [1] play an important role in the capture and storage of atmospheric carbon, which is of global importance and can mitigate the effects of ST in SPEI-24. The methodology proposed in this paper is an efficient way to predict droughts; that is, quantifying the impacts of climate change at the local level, even when extensive time series ( $>50$ years) or powerful computing resources are not available. The $S T$ of $T_{a v g}$ are higher than those of Prec. Due to the $S T$ of $T_{a v g}, P E T$, and SPEI-24, it is essential to make changes in the way economic activities such as agriculture and aquaculture are scheduled in northern Mexico. It is essential to carry out studies of this nature in regions where the water resources resulting from Prec exceed $60 \%$ of the annual cumulative total, as is the case in the agricultural sector of northern Mexico.

The methodology proposed in this research to predict droughts can be applied to any region of Mexico and the world simply by using the appropriate $T_{a v g}$ and Prec indicators. One of the limitations of the IDW interpolation method is that the spatial distribution of the variables depends only on the distances between the weather stations. In order to improve the interpolation on the maps, the number of years of daily data $(n>50)$ and the number of weather stations would need to be increased and the distance between them $(<25 \mathrm{~km})$ reduced. In the literature, no studies were found that analyzed the $S T$ of the SPEI-24 index or RP of droughts in northwest Mexico. Worldwide, no studies were found analyzing the $S T$ of SPEI-24. The trends calculated for $T_{a v g}$ and Prec were similar to the results obtained by [39]. The correlation coefficients were 0.916 for $T_{\text {avg }}$ and 0.799 for Prec, which validates the results of this study.

\section{Acknowledgements}

Thanks are extended to the Research and Postgraduate Secretariat of the National Polytechnic Institute (SIP-IPN) for economic support provided through individual projects 20151916 and 20160664.

\section{References}

1. INTERGOVERNMENTAL PANEL ON CLIMATE CHANGE (IPCC). Climate Chante 2013: The Physical Science Basis. 33, 2013.

2. WILHITE D.A., GLANTZ M.H. Understanding the drought phenomenon: The role of definitions. Water Int., 10, 111, 1985.

3. GUTTMAN B.N. Accepting the standardized precipitation index: a calculation algorithm. J. Am. Water Res. Assoc. 35 (2), 311, 1999.

4. KOMUSCU A.U. Using the SPI to analyze spatial and temporal drought patterns in Turkey. Drought Network News 11 (1), 7, 1999.

5. WILHITE D.A. Drought as a natural hazard. In: Drought: A Global Assessment. Wilhite, D.A. (ed). Routledge Publishers, London, UK. 3, 2000.

6. VALIENTE O. "Drought: definitions, typologies and methods of quantification. España. Investigaciones Geográficas $N^{\circ} 26$. Instituto Universitario de Geografía. Universidad de Alicante, 59, 2001.

7. SERRANO V.S.M, BEGUERÍA S., LÓPEZ M.J.I. A multiscalar drought index sensitive to global warming: the Standardized Precipitation Evapotranspiration Index - SPEI. Journal of Climate 23, 1696, 2010.

8. SERRANO V.S.M., BEGUERÍA S., LORENZO L.J., CAMARERO J.J., LÓPEZ M.J.I., AZORÍN M.C., REVUELTO J., MORÁN T.E., SÁNCHEZ L.A. Comparative analysis of different drought indices for ecological, agricultural and hydrological applications. 
Cambio climático. Extremos e impactos. $8^{\circ}$ Congreso Internacional de la Asociación Española de Climatología (AEC) (Salamanca, Sept. 25-28, 2012), 2012.

9. YU M., LI Q., HAYES M.J., SVOBODAB M.D., HEIM R.R. Are droughts becoming more frequent or severe in China based on the Standardized Precipitation Evapotranspiration Index: 1951-2010?, Int. J. Climatol., 34, 545, 2014.

10. MÉNDEZ M., MAGAÑA V. Regional Aspects of Prolonged Meteorological Droughts over Mexico and Central American, Journal of Climate, 1175, 2010.

11. BORDI I., FRIGIO S., PARENTI P., SPERANZA A., SUTERA A. The analysis of the Standardized Precipitation Index in the Mediterranean area: large-scale patterns. Annali Di Geofisica, 44, 965, 2001.

12. ASKEW A, ROODA J. Addressing arid zone problems. L'hydrologie tropicale: géoscience et outil pour le développement (Actes de la conférence de Paris, mai 1995). IAHS Publ., 238, 1996.

13. BRANT S. Assessing vulnerability to drought in Ceará, northeast Brazil. A thesis submitted in partial fulfillment of the requirements for the degree of Master of Science (Natural Resources and Environment) University of Michigan, 2007.

14. CROMPTON R., McANENENEY J. The cost of natural disasters in Australia: The case for disaster risk reduction, The Australian Journal of Emergency Management, 23 (4), 43, 2008.

15. CENTRO NACIONAL DE PREVENCIÓN DE DESASTRES (CENAPRED). Diagnosis of hazards and identification of disaster risk in Mexico, D.F., 2001 [In Spanish].

16. COMISIÓN NACIONAL DE LAS ZONAS ÁRIDASSECRETARÍA DE AGRICULTURA, GANADERÍA, DESARROLLO RURAL, PESCA Y ALIMENTACIÓN (CONAZA-SAGARPA). Analysis of the drought problem 2011-2012 and its effects on livestock and seasonal agriculture, México, 12, 2011 [In Spanish].

17. ROJAS E., ARCE B., PEÑA A., BOSHELL F., AYARZA M. Quantification and interpolation of local temperature and precipitation trends in high Andean zones of Cundinamarca and Boyacá (Colombia). Revista Corpoica - Ciencia y Tecnología Agropecuaria: 11 (2), 173, 2010.

18. LLANES C.O., NORZAGARAY C.M., MUÑOZ S.P., RUIZ G.R., GONZÁLEZ O.H.A., HERRERA M.M.N. Estimating Trends and Return Periods of Daily Extreme Precipitation Associated with Tropical Cyclones in the Core North American Monsoon. Pol. J. Environ. Stud., 25 (6), 1, 2016. DOI: $10.15244 /$ pjoes/64161.

19. THORNTHWAITE C.W. An approach toward a rational classification of climate.Geographical Review 38, 55, 1948.

20. YUE S., PILON P., CAVADIAS G. Power of the MannKendall and Spearman>s rho tests for detecting monotonic trends in hydrological series. Journal of Hydrology, 259, 254, 2002.

21. SEN P.K. Estimates of the regression coefficient based on Kendall's Tau, J. Am. Stat. Assoc., 63, 1379, 1968.

22. PODESTÁ G., SKANSI M.M., HERRERA N., VEIGA H. Description of indexes for the meteorological drought monitoring implemented by the Regional Climate Center for South South America. Reporte Técnico CRC-SAS-2015-001, 27, 2016 [In Spanish].

23. KOUTSOYIANNIS D. "On the appropriateness of the Gumbel Distribution in modeling extreme rainfall", Proceedings of the ESF LESC Exploratory Workshop held at Bologna, Italy, October 24-25, 303, 2003.

24. NORZAGARAY C.M., MUÑOZ S.P., SÁNCHEZ V.L., CAPURRO F.L., LLANES C.O. Aquaculture: Current status and research challenges in Mexico. Revista AquaTIC. 37 (1), $1,2012$.

25. LLANES C.O., NORZAGARAY C.M., MAYA D.Y., MUÑOZ S.P., BELTRÁN M.F.A., MURILLO A.B., TROYO D.E. Hydroenvironmental effects of water extraction from the Sinaloa River aquifer. Universidad y Ciencia. 27 (3), 239, 2011.

26. ALIANZA PARA LA SUSTENTABILIDAD DEL NOROESTE COSTERO MEXICANO (ALCOSTA). Towards sustainable tourism on the northeast coast of Mexico. Mexico City, 2011.

27. INSTITUTO NACIONAL DE ESTADÍSTICA Y GEOGRAFÍA (INEGI). Mexican National Institute of Geography and Statistics 2011 Statistical yearbook by state. México, ISSN 1405-910X, D.F., 2011

28. INSTITUTO NACIONAL DE ESTADÍSTICA Y GEOGRAFÍA (INEGI). Mexican National Institute of Geography and Statistics. Second Population and Housing Census 2005. Main results by locality, 2010.

29. LLANES C.O., NORZAGARAY C.M., MUÑOZ S.P., RUIZ G.R. Groundwater: Aquaculture alternative in northeast Mexico. Revista AquaTIC, Zaragoza Spain, 38, 10, 2013.

30. KUMAR V., JAIN S.K. Trends in seasonal and annual rainfall and rainy days in Kashmir Valley in the last century. Quatern. Int., 212 (1), 64, 2010. doi:10.1016/j.quaint.2009.08.006

31. KAHYA E., KALAYCI S. Trend analysis of streamflow in Turkey. J. Hydrol., 289 (1-4), 128, 2004.

32. YUNLING H., ZHANG Z. Climate Change from 1960 to 2000 in the Lancang River Valley, China. Mt. Res. Dev. 25 (4), 341, 2005.

33. AKSU H., KOSCU S., SIMSEK O. Trend analysis of hydrometeorological parameters in climate regions of Turkey. In: State Hydraulic Works, 2010.

34. BAUTISTA F.A., BAUTISTA H.D.A. ÁlVAREZ O., ANAYA ROMERO M., DE LA ROSA D. Software for identifying climate change trends at the local level: A case study in Yucatán, Mexico. Revista Chapingo. Serie de Ciencias Forestales y del Ambiente: 19 (1), 81, 2013.

35. VAN BELLE G., HUGHES J. P. Nonparametric Tests for Trend in Water Quality, 20 (1), 127, 1984.

36. DÍAZ P., SÁNCHEZ I., QUIROZ R., GARATUZA P., WATTS T., CRUZ I. Spatial interpolation of rainfall precipitation in the windward and leeward zone of the Gulf of Mexico. Agricultura Técnica en México 34 (3), 279, 2008.

37. GUTIÉRREZ L.J., VARGAS T.V., ROMERO R.M., DE LA CRUZ J.M.P., AGUIRRE B.M.J., SILVA E.H.T. Return periods of torrential rains for the state of Tamaulipas, Mexico. Investigaciones Geográficas, Boletín del Instituto de Geografía, UNAM, 76, 20, 2011 [In Spanish].

38. AGUILERA N.M.A. Estimation of probability distribution functions, for maximum flows, in the Maule region. Tesis de Licenciatura de la Universidad de TALCA, Facultad de Ciencias Forestales, Chile, 154, 2007 [In Spanish].

39. PROGRAMA DE LAS NACIONES UNIDAS PARA EL DESARROLLO-SECRETARÍA DE MEDIO AMBIENTE Y RECURSOS NATURALES (PNUD-SEMARNAT). Diagnosis of current trends in extreme weather phenomena and projection of their activity to the near future climate 2030 and far future climate 2080. Considering the effects of global climate change and other local effects. Taller: Estudios sobre vulnerabilidad y adaptación al cambio climático de la quinta comunicación nacional de México ante la C MNUCC. Febrero 2012. México D. 23, 2012 [In Spanish].

40. PRESS W.H., TEUKOLSKY S.A, VETTERLING W.T., FLANNERY B.P. Numerical Recipes in C. Cambridge University Press, 1992. 
41. VILLASENOR A.J.A., GONZÁLEZ E.E. A generalization of Shapiro-Wilk test for multi-variate normality. Communications in Statistics - Theory and Methods, 38, $1870,2009$.

42. HAMMER Ø. PAleontological STatistics Version 3.14 Reference manual, 1, 2016.

43. STERN N.H., TREASURY G.B. The Economics of Climate Change: The Stern Review, Cambridge University Press, 2007.

44. STOCKER T., QIN D., PLATTNER G.K., TIGNOR M., ALLEN S.K., BOSCHUNG J., NAUELS A., XIA Y., BEX V., MIDGLEY P.M. Climate Change 2013: The Physical Science Basis. Cambridge University Press: Cambridge, UK and New York, NY., 2014.

45. MANSO O.M.D.J., VENTURA M., CHAGAS G., RODRÍGUEZ A., CARVALHEIRO L. Characteristics of the annual evapotranspiration trend in the Duero Basin. 509, 2012 [In Spanish].

46. NING T., LI Z., LIU W., HAN X. Evolution of potential evapotranspiration in the northern Loess Plateau of China: recent trends and climatic drivers. Int. J. Climatol. 36, 4019, 2016.
47. COMISIÓN NACIONAL DEL AGUA (CONAGUA) Historical Standardized Precipitation (SPI) index data from 1951 to 2016 for the different periods, 2016 [In Spanish].

48. OJEDA B.W., SIFUENTES I.E., ÍÑIGUEZ C.M., MONTERO M.M.J. Impact of climate change on crop water needs and development. Agrociencia 45, 1, 2011

49. SECRETARÍA DE MEDIO AMBIENTE Y RECURSOS NATURALES (SEMARNAT). Wetlands: First workshop on Ramsar sites in Baja California Sur. Mexico, 2011 [In Spanish].

50. ORGANIZACIÓN DE LAS NACIONES UNIDAS PARA LAALIMENTACIÓN Y LA AGRICULTURA (FAO). Basic principles of conservation agriculture. Food and Agriculture Organization of the United Nations. Departamento de Agricultura y Protección del Consumidor-Agricultura de conservación, 2015 [In Spanish].

51. MINGWEI M., SONGBAI S., LILIANG R., SHANHU J., JIALI S. Multivariate drought characteristics using trivariate Gaussian and Student t copulas. Hydrol. Process. 27, 1175, 2013. 